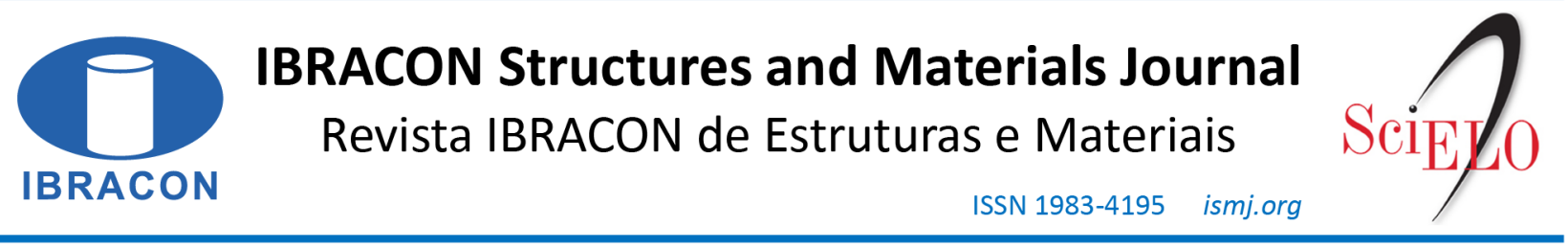

ORIGINAL ARTICLE

\title{
Reliability analysis of slender columns using the general method with linear creep theory
}

\author{
Análise da confiabilidade de pilares esbeltos usando o método geral com a teoria \\ linear da fluência \\ Kleyser Ribeiro ${ }^{\mathrm{a}}$ \\ Daniel Domingues Loriggio $^{\mathrm{a}}$ \\ Mauro de Vasconcellos Real ${ }^{\mathrm{b}}$ (D)

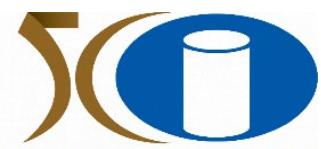 \\ YEARSIBRACON
}

${ }^{a}$ Universidade Federal de Santa Catarina - UFSC, Florianópolis, SC, Brasil

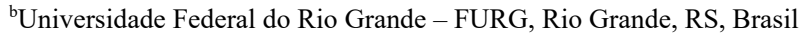

Received 21 April 2021

Accepted 11 October 2021

\begin{abstract}
To analyze the reliability of slender columns subjected to axial force and uniaxial bending moment, with a slenderness index between 100 and 140, 216 columns were modeled. The square cross-section was adopted, with three different configurations for longitudinal reinforcement. In the calculation, the general method with the linear creep theory was applied. Several factors were varied: slenderness index, reinforcement ratio, steel bars arrangement, compressive strength of concrete, and first-order relative eccentricity. For analysis purposes, the Monte Carlo method was adopted, followed by the First Order Reliability Method (FORM). Considering the results obtained, it was observed that the reliability index is usually higher for lower reinforcement ratios and varies according to the configuration of the cross-section.
\end{abstract}

Keywords: slender columns, reliability, general method, Monte Carlo, FORM.

Resumo: Buscando-se analisar a confiabilidade de pilares esbeltos submetidos a flexo-compressão normal, com índice de esbeltez entre 100 e 140, realizou-se a modelagem de 216 elementos. Adotou-se a seção transversal quadrada, com três configurações distintas para armadura longitudinal. No cálculo, aplicou-se o método geral com a teoria linear da fluência. Efetuou-se a variação de diversos fatores, incluindo-se: índice de esbeltez, taxa de armadura, disposição das barras de aço, resistência do concreto e excentricidade relativa de primeira ordem. Para fins de análise, adotou-se o método de Monte Carlo seguido pelo FORM. Considerando-se os resultados obtidos, observou-se que o índice de confiabilidade comumente é maior para taxas de armadura inferiores e sofre variação de acordo com a configuração da seção transversal.

Palavras-chave: pilares esbeltos, confiabilidade, método geral, Monte Carlo, FORM.

How to cite: K. Ribeiro, D. D. Loriggio, and M. V. Real, "Reliability analysis of slender columns using the general method with linear creep theory," Rev. IBRACON Estrut. Mater., vol. 15, no. 3, e15308, 2022, https://doi.org/10.1590/S1983-41952022000300008

\section{INTRODUCTION}

To evaluate the reliability of slender reinforced concrete columns, designed according to the Brazilian Standard NBR 6118 [1], a numerical analysis was conducted with 216 columns, and these columns were modeled to failure exclusively for this research. For the parametric analysis, the following variations were considered: slenderness index, compressive strength of concrete, first-order relative eccentricity, reinforcement ratio, and arrangement of steel bars in the cross-section.

The study was limited to columns of square cross-section, constant along with the height, with slenderness index between 100 and 140. Cantilever columns with compressive load and moment due to the force eccentricity were 
considered. The general method was used in all cases, determining the moment-curvature relationship and, subsequently, calculating the second-order local effects by finite difference method.

The numeric analysis was proposed to answer the question "what is the influence of the longitudinal reinforcement on the reliability of slender columns?" The main objective was to analyze the structural reliability of columns with a slenderness index between 100 and 140 to verify whether the safety level is adequate for building design.

This study is justified by the current usual slenderness of elements designed in buildings in Brazil, mainly with high strength concrete. Besides, there is few research emphasizing columns with a slenderness index greater than 90, designed including creep behavior and accurately considering physical and geometric nonlinearities.

Among the methodological procedures, computational development and numerical simulations were adopted, followed by statistical methods to analyze the results, based on Magalhães [2], Damas [3] and Barbosa [4].

\section{GENERAL METHOD}

The general method is defined as the one in which both physical and geometric nonlinearities are considered precisely. Therefore, the curvature in each section is determined using the moment-curvature relationship. Regarding the second-order local effects, it was decided to implement the finite difference method.

\subsection{Moment-curvature relationship}

The moment-curvature relationship was implemented based on Ribeiro [5], according to the flowchart in Figure 1.

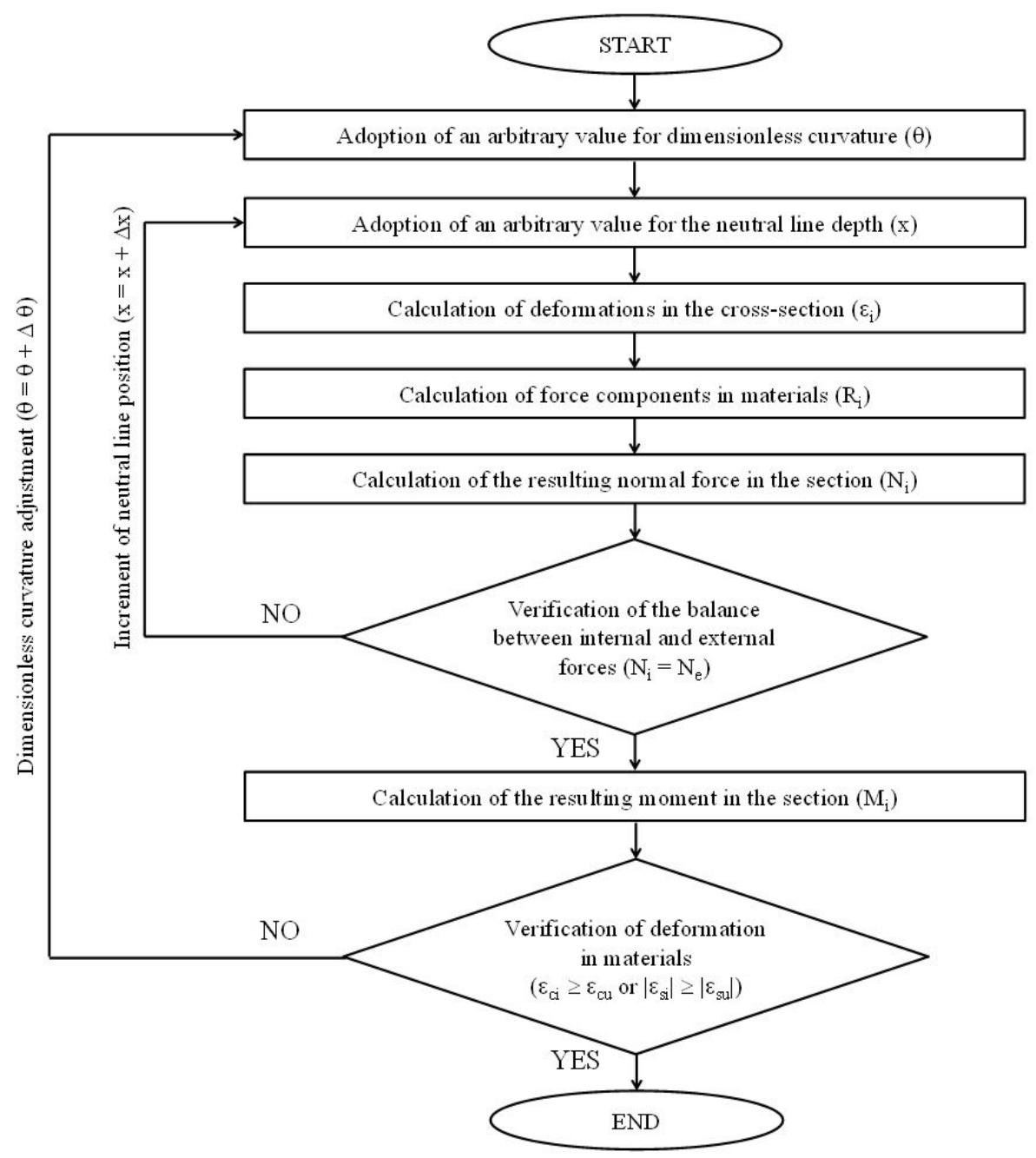

Figure 1. Flowchart of the moment-curvature relationship. 
The dimensionless curvature $\theta$ was defined from Equation 1, depending on the overall depth of the cross-section $\mathrm{h}$ and the curvature 1/r. The curvature, as usually defined in the fundamentals of Solid Mechanics, is given by Equation 2.

$$
\theta=1000 \mathrm{~h} \frac{1}{\mathrm{r}}
$$

$$
\frac{1}{\mathrm{r}}=\frac{\mathrm{M}}{\mathrm{EI}}
$$

where $\mathrm{M}$ is the section bending moment and EI represents the flexural stiffness.

Two curves were considered for design, considering either the limit of $0.85 f_{\mathrm{cd}}$ or $1.10 f_{\mathrm{cd}}$, according to the Brazilian Standard NBR 6118 [1]. The design value of the concrete compressive strength $\left(f_{\mathrm{cd}}\right)$ is the quotient between the concrete characteristic compressive strength $\left(f_{\mathrm{ck}}\right)$ and the concrete partial material safety factor, given by $\gamma_{\mathrm{c}}=1.4$. In this case, the second curve is limited to the ultimate design moment $\left(\mathrm{M}_{\mathrm{Rd}}\right)$ determined from the first. The moment-curvature relationship for design situations is shown in Figure 2.

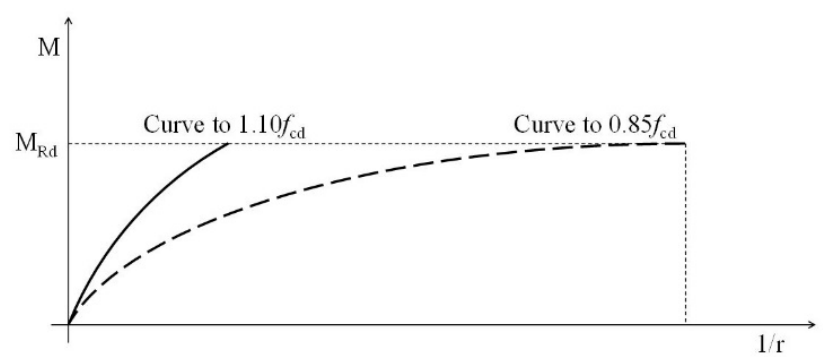

Figure 2. Moment-curvature diagram according to the Brazilian Standard NBR 6118 [1].

For mechanical modeling purposes, the safety factors are not used, and some adjustments must be made in the diagram, aiming to simulate the actual physical behavior of the columns. To determine the ultimate load, corresponding to the maximum load in experimental tests, the curve coefficients are not used in the numerical model either. In this case, a single curve is drawn using the average concrete compressive strength $f_{\mathrm{cm}}$ instead of $f_{\text {cd }}$ and the ultimate moment is determined.

\subsection{Finite Difference Method}

Second-order effects were determined using the finite difference method. Given a cantilever column of length $\mathrm{L}$, the member is divided into $\mathrm{n}$ equidistant sections of $\Delta \mathrm{x}$, positioning the origin of the Cartesian system according to Figure 3 .

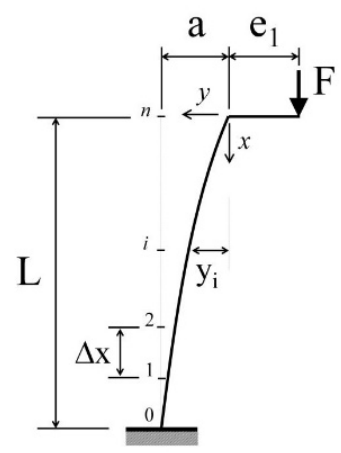

Figure 3. Cantilever column for application of the finite difference method. 
The values of the normal force $(F)$ and the first-order eccentricity $\left(\mathrm{e}_{1}\right)$ were admitted constant, with the variation of the maximum displacement (a) at the column top from zero until convergence. It was assumed that $\mathrm{y}_{0}=\mathrm{a}$. Equation 3 is used to calculate the displacement $\left(\mathrm{y}_{\mathrm{i}}\right)$ in section $\mathrm{i}=1$ and Equation 4 for the other points. The calculation algorithm is represented in the flowchart in Figure 4.

$$
\begin{aligned}
& \mathrm{y}_{1}=\mathrm{y}_{0}-\frac{\Delta \mathrm{x}^{2}}{2}\left(\frac{1}{\mathrm{r}}\right)_{0} \text { if } i=1 \\
& \mathrm{y}_{\mathrm{i}+1}=2 \mathrm{y}_{\mathrm{i}}-\mathrm{y}_{\mathrm{i}-1}-\Delta \mathrm{x}^{2}\left(\frac{1}{\mathrm{r}}\right)_{\mathrm{i}} \text { if } i>1
\end{aligned}
$$

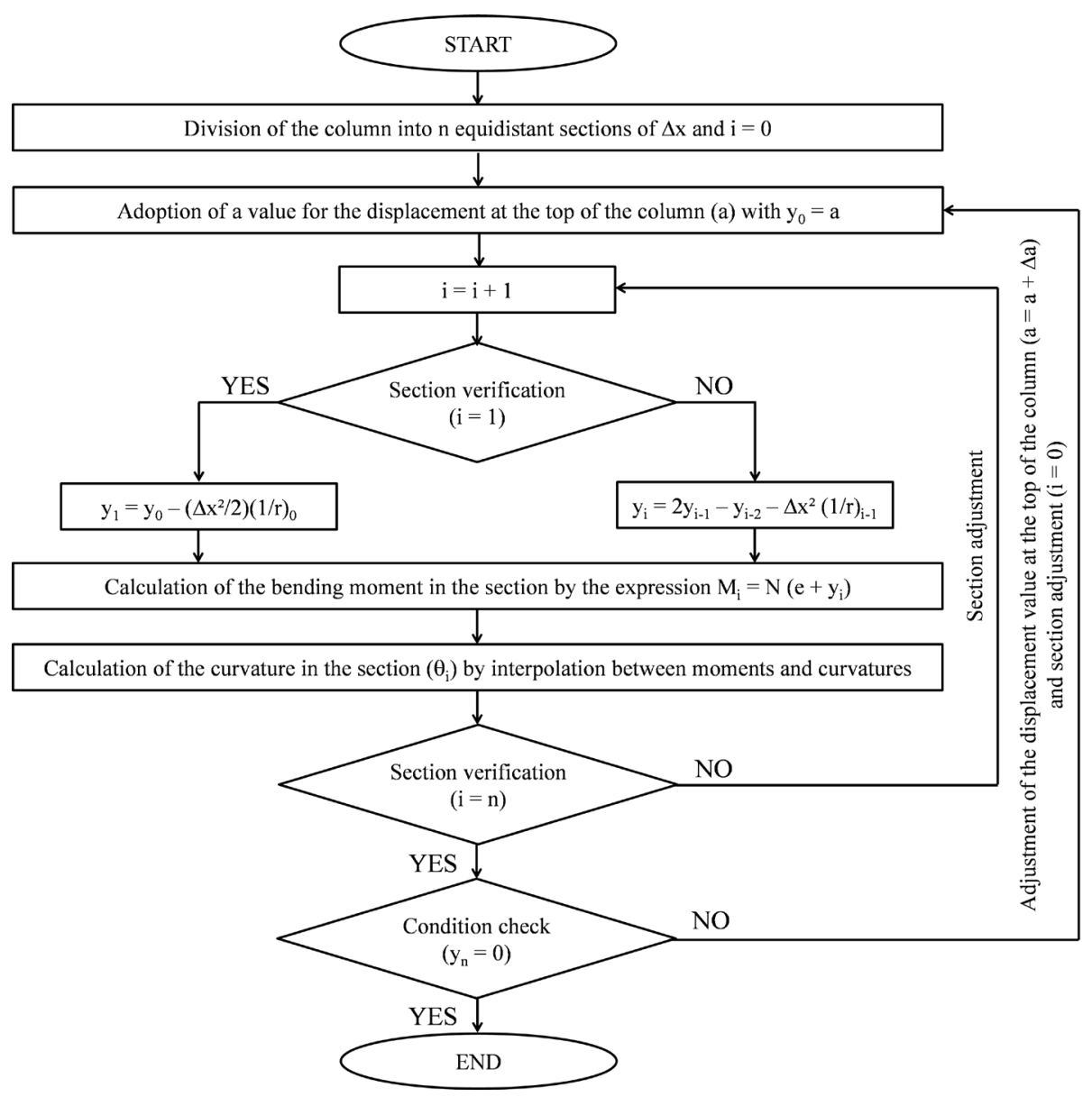

Figure 4. Flowchart of the finite difference method.

\section{CONSTITUTIVE MODELS}

\subsection{Constitutive design models}

\subsubsection{Constitutive model of concrete}

To verify the design strength, the parabola-rectangle diagram proposed by the Brazilian Standard NBR 6118 [1] was considered to represent the behavior of the concrete subjected to compression, as shown in Figure 5, where $\sigma_{\mathrm{c}}$ represents the stresses and $\varepsilon_{\mathrm{c}}$ represents the strains. The creep displacement was considered according to the linear creep theory adopting a creep coefficient. In practice, the effective creep coefficient $\phi_{\mathrm{ef}}=1.18$ was used, referring to the creep coefficient $\phi=2$ and the condition in which 75\% of the loads are of long-term, based on Fusco [6] and Casagrande [7]. 
The creep coefficient value was kept constant in all columns modeled allowing to analyze the influence of the other parameters. The concrete design strength, $f_{\mathrm{cd}}$, must be calculated from Equation 5 as a function of the characteristic compressive strength of concrete $\left(f_{\text {ck }}\right)$, where $\gamma_{\mathrm{c}}=1.4$ was admitted. This constitutive relationship is valid for $20 \leq f_{\mathrm{ck}} \leq$ $90 \mathrm{MPa}$ and can be represented by Equations 6 to 9 .

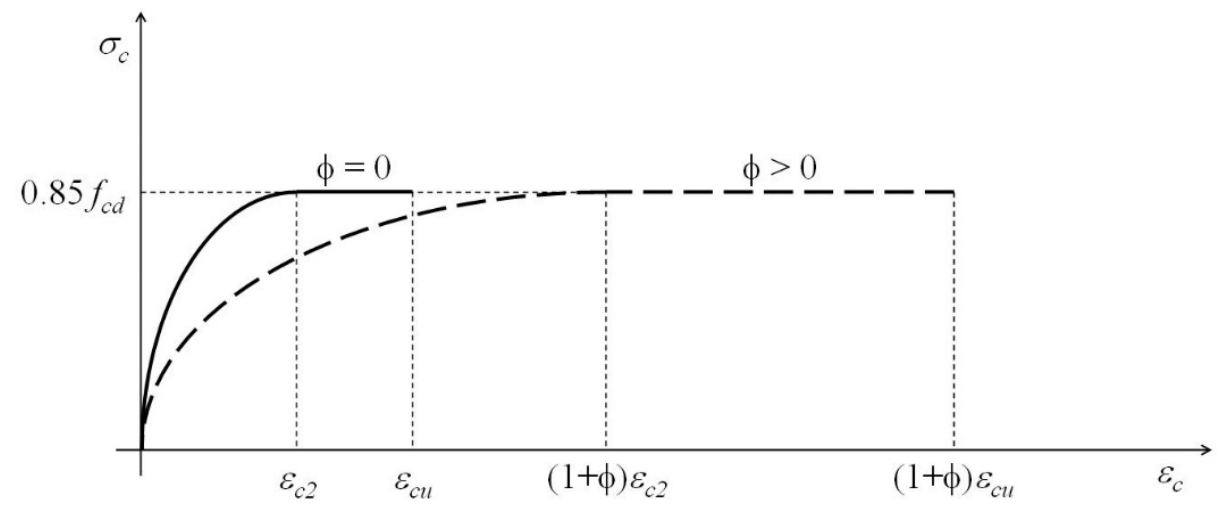

Figure 5. Simplified stress-strain diagram of concrete with creep.

$f_{\text {cd }}=\frac{f_{c k}}{\gamma_{c}}$

$\sigma_{\mathrm{c}}=0.85 \mathrm{f}_{\mathrm{cd}}\left[1-\left(1-\frac{\varepsilon_{\mathrm{c}}}{\varepsilon_{\mathrm{c} 2}}\right)^{\mathrm{n}}\right]$ for $0 \leq \varepsilon_{\mathrm{c}} \leq \varepsilon_{\mathrm{c} 2}$

$\sigma_{\mathrm{c}}=\mathrm{f}_{\mathrm{cd}}$ for $\varepsilon_{\mathrm{c} 2}<\varepsilon_{\mathrm{c}} \leq \varepsilon_{\mathrm{cu}}$

where

$\mathrm{n}=2$ if $\mathrm{f}_{\mathrm{ck}} \leq 50 \mathrm{MPa}$

$\mathrm{n}=1.4+23.4\left[\left(90-\mathrm{f}_{\mathrm{ck}}\right) / 100\right]^{4}$ if $\mathrm{f}_{\mathrm{ck}}>50 \mathrm{MPa}$

Concerning the deformation limits, the values were calculated from Equations 10 to 13 .

$\varepsilon_{\mathrm{c} 2}=2.0 \%$ if $\mathrm{f}_{\mathrm{ck}} \leq 50 \mathrm{MPa}$

$\varepsilon_{\mathrm{c} 2}=\left\{2.0+0.085\left(\mathrm{f}_{\mathrm{ck}}-50\right)^{0.53}\right\} \%$ if $\mathrm{f}_{\mathrm{ck}}>50 \mathrm{MPa}$

$\varepsilon_{\mathrm{cu}}=3.5 \%$ if $\mathrm{f}_{\mathrm{ck}} \leq 50 \mathrm{MPa}$

$\varepsilon_{\mathrm{cu}}=\left\{2.6+35\left[\left(90-\mathrm{f}_{\mathrm{ck}}\right) / 100\right]^{4}\right\} \%$ if $\mathrm{f}_{\mathrm{ck}}>50 M P a$ 
However, these values are changed by creep using the effective coefficient $\phi_{\mathrm{ef}}$, according to Equations 14 and 15 .

$\varepsilon_{\mathrm{c} 2, \mathrm{ef}}=\left(1+\phi_{\mathrm{ef}}\right) \varepsilon_{\mathrm{c} 2}$

$\varepsilon_{\mathrm{cu}, \mathrm{ef}}=\left(1+\phi_{\mathrm{ef}}\right) \varepsilon_{\mathrm{cu}}$

\subsubsection{Constitutive model of steel}

The simplified stress-strain diagram of Brazilian Standard NBR 6118 [1] for longitudinal reinforcement was adopted, considering the perfect elasto-plastic behavior of steel for reinforced concrete, as shown in Figure 6. It should be noted that this reinforcement diagram is valid for both compression and tension. The models consider $f_{\mathrm{yk}}=500 \mathrm{MPa}$ for the characteristic yield strength of reinforcement, $E_{\mathrm{s}}=210 \mathrm{GPa}$ for the design value of modulus of elasticity of reinforcing steel, and $\varepsilon_{\mathrm{su}}=10 \%$ for the ultimate strain.

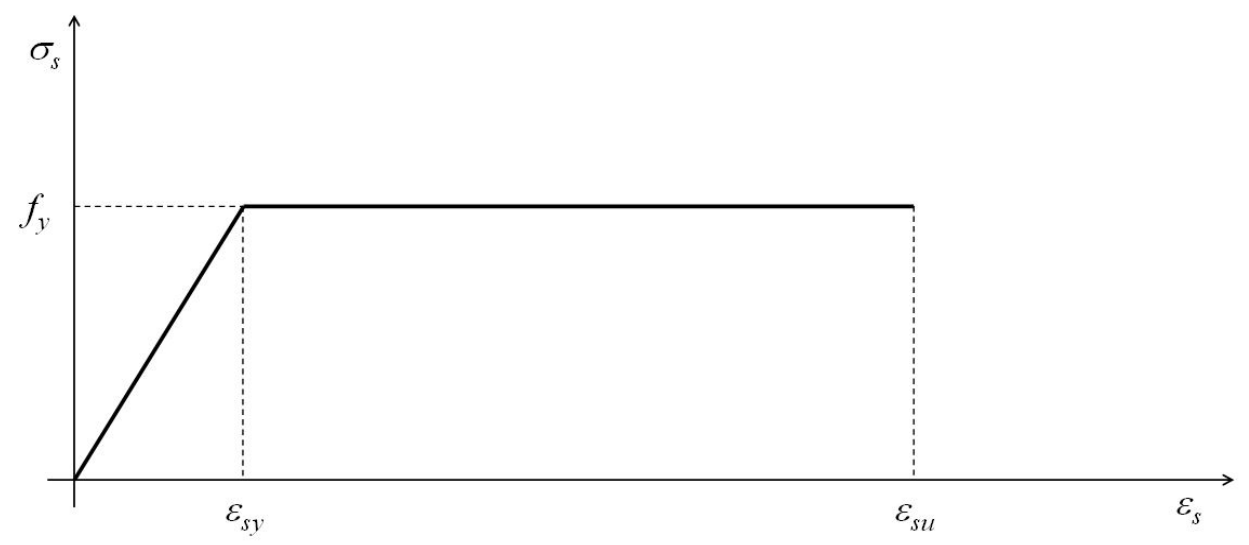

Figure 6. Simplified stress-strain diagram for longitudinal reinforcement.

For design situations, the design yield strength of reinforcement $f_{\mathrm{yd}}$ was calculated from Equation 16 , where $\gamma_{\mathrm{s}}=$ 1.15 is admitted as the partial factor for reinforcing steel.

$$
f_{y d}=\frac{f_{y k}}{\gamma_{s}}
$$

\subsection{Mechanical model}

For determining the ultimate loads, the constitutive model presented in item 3.1.2 was used for longitudinal reinforcement without the safety coefficients. For concrete, the models shown below were used.

\subsubsection{Compression in concrete}

The non-linear model of Eurocode 2 [8] for the concrete subjected to compression was used to represent the column behavior in rupture, as shown in Figure 7. This constitutive model can be represented by Equations 17 to 19, using the average value of concrete compressive strength $f_{\mathrm{cm}}$ and the secant modulus of elasticity of concrete $\mathrm{E}_{\mathrm{cm}}$.

$$
\frac{\sigma_{\mathrm{c}}}{\mathrm{f}_{\mathrm{cm}}}=\frac{\mathrm{k} \eta-\eta^{2}}{1+(\mathrm{k}-2) \eta}
$$


where

$\eta=\frac{\varepsilon_{\mathrm{c}}}{\varepsilon_{\mathrm{c} 1}}$

$\mathrm{k}=1.05 \frac{\mathrm{E}_{\mathrm{cm}}}{\mathrm{f}_{\mathrm{cm}}}\left|\varepsilon_{\mathrm{cl}}\right|$

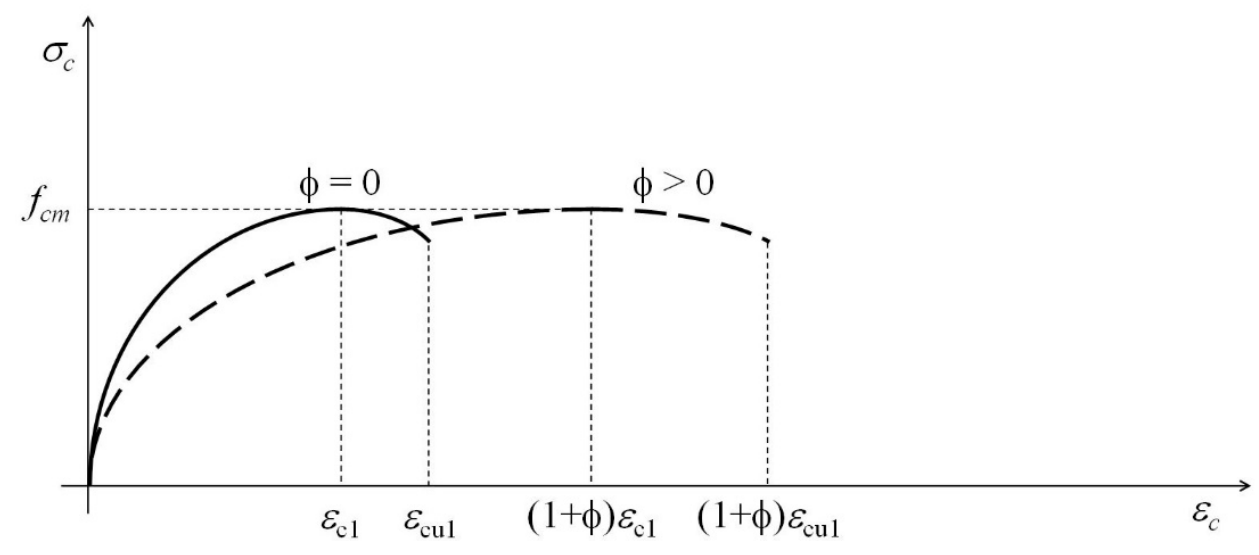

Figure 7. Constitutive model for non-linear analysis with creep.

In Figure 7, $\varepsilon_{\mathrm{c}}$ is the compressive strain, $\varepsilon_{\mathrm{cl}}$ represents the compressive strain at the peak stress, and $\varepsilon_{\mathrm{cu}}$ represents the ultimate compressive strain in the concrete.

The values of $\mathrm{E}_{\mathrm{cm}}, \varepsilon_{\mathrm{cl}}$ and $\varepsilon_{\mathrm{cu} 1}$ were obtained from Equations 20 to 23 , considering the value of $f_{\mathrm{cm}}$ in MPa.

$\mathrm{E}_{\mathrm{cm}}=22\left(\mathrm{f}_{\mathrm{cm}} / 10\right)^{0.3} \mathrm{GPa}$

$\varepsilon_{\mathrm{c} 1}=0.7 \mathrm{f}_{\mathrm{cm}}^{0.31} \% \leq 2.8 \%$

$\varepsilon_{\mathrm{cul}}=3.5 \%$ if $\mathrm{f}_{\mathrm{ck}} \leq 50 \mathrm{MPa}$

$\varepsilon_{\mathrm{cul}}=\left\{2.8+27\left[\left(98-\mathrm{f}_{\mathrm{cm}}\right) / 100\right]^{4}\right\} \%$ if $\mathrm{f}_{\mathrm{ck}}>50 M P a$

Also, creep effects must be considered, according to Equations 24 and 25.

$\varepsilon_{\mathrm{cl} 1, \mathrm{ef}}=\left(1+\phi_{\mathrm{ef}}\right) \varepsilon_{\mathrm{cl}}$

$\varepsilon_{\mathrm{cu} 1, \mathrm{ef}}=\left(1+\phi_{\mathrm{ef}}\right) \varepsilon_{\mathrm{cu} 1}$

\subsubsection{Tension in concrete}

The tensile strength and the tension-stiffening effect of the concrete were admitted, based on the simplified model adapted by Baptista [9] from Collins and Mitchell [10]. This model is shown in Figure 8, where $f_{\text {cr }}$ represents the 
cracking stress, $\varepsilon_{\text {cr }}$ represents the strain corresponding to the cracking, and $\varepsilon_{\text {sy }}$ represents the yield strain of reinforcement.

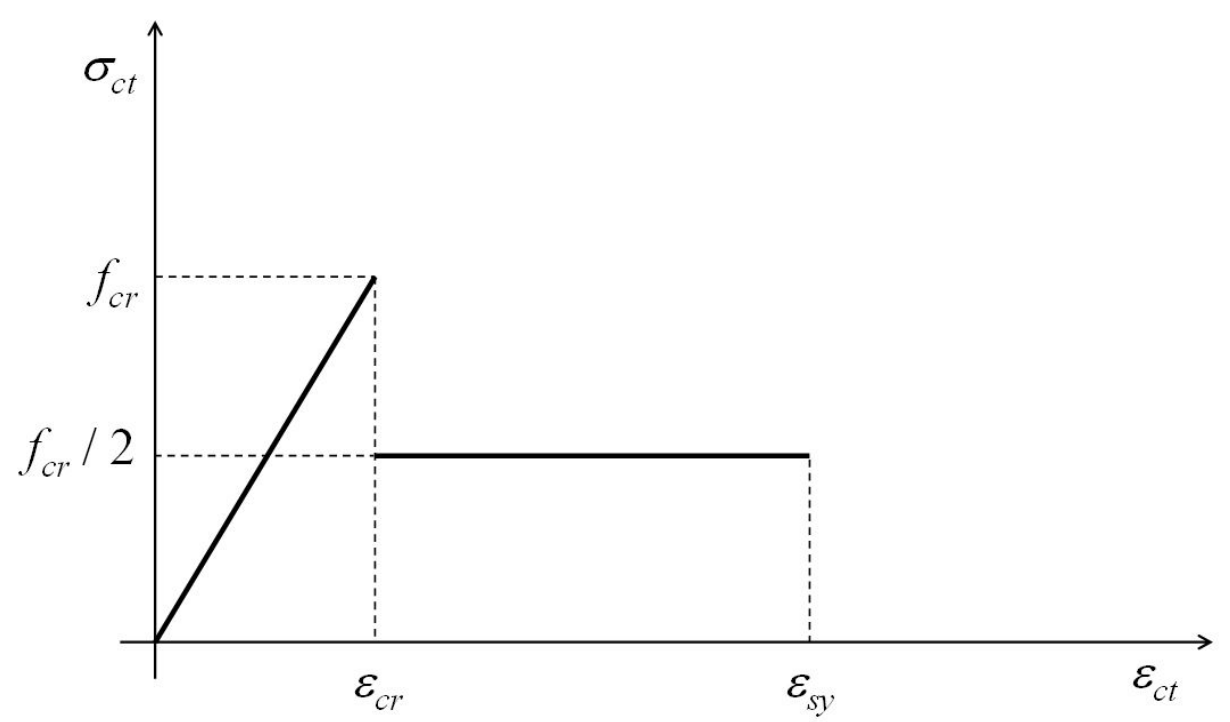

Figure 8. Constitutive model for tension in concrete with tension-stiffening effect.

For the cracking stress $f_{\mathrm{cr}}$, the flexural tensile strength $f_{\mathrm{ctm}, \mathrm{fl}}$ of Eurocode 2 [8] was considered, with the application of Equation 26.

$\mathrm{f}_{\mathrm{ctm}, \mathrm{fl}}=\max \left\{(1.6-\mathrm{h} / 1000) \mathrm{f}_{\mathrm{ctm}} ; \mathrm{f}_{\mathrm{ctm}}\right\}$

where $\mathrm{h}$ is the overall depth of the section in $\mathrm{mm}$ and $f_{\mathrm{ctm}}$ is the mean axial tensile strength given by Equations 27 and 28.

$\mathrm{f}_{\mathrm{ctm}}=0.30 \mathrm{f}_{\mathrm{ck}}^{2 / 3}$ if $\mathrm{f}_{\mathrm{ck}} \leq 50 M P a$

$\mathrm{f}_{\mathrm{ctm}}=2.12 \ln \left(1+\left(\mathrm{f}_{\mathrm{cm}} / 10\right)\right)$ if $\mathrm{f}_{\mathrm{ck}}>50 M P a$

In Equation 27, $f_{\mathrm{ck}}$ is used, while in Equation 28, $f_{\mathrm{cm}}$ is used. The considered relationship between the two variables is given in Equation 29.

$\mathrm{f}_{\mathrm{cm}}=\mathrm{f}_{\mathrm{ck}}+8(M P a)$

It is considered that the tension stresses act in a rectangular block, corresponding to the effective tension area of the cross-section, based on Eurocode 2 [8], as shown in Figure 9. The block is defined by the width of the cross-section b and the effective tension depth $\mathrm{h}_{\mathrm{c}, \mathrm{ef}}$, given by Equation 30 .

$\mathrm{h}_{\mathrm{c}, \mathrm{ef}}=\min \left\{2.5(\mathrm{~h}-\mathrm{d}) ; \frac{\mathrm{h}-\mathrm{y}_{\mathrm{LN}}}{3}\right\}$ 
where $h$ is the overall depth of the cross-section, $d$ is the effective depth of the cross-section, and $y_{L N}$ is the depth of the neutral line in relation to the most compressed fiber.

Then, it is possible to obtain the effective tension area $\mathrm{A}_{\mathrm{c}, \mathrm{ef}}$ by Equation 31.

$\mathrm{A}_{\mathrm{c}, \mathrm{ef}}=\mathrm{bh} \mathrm{h}_{\mathrm{c}, \mathrm{ef}}$

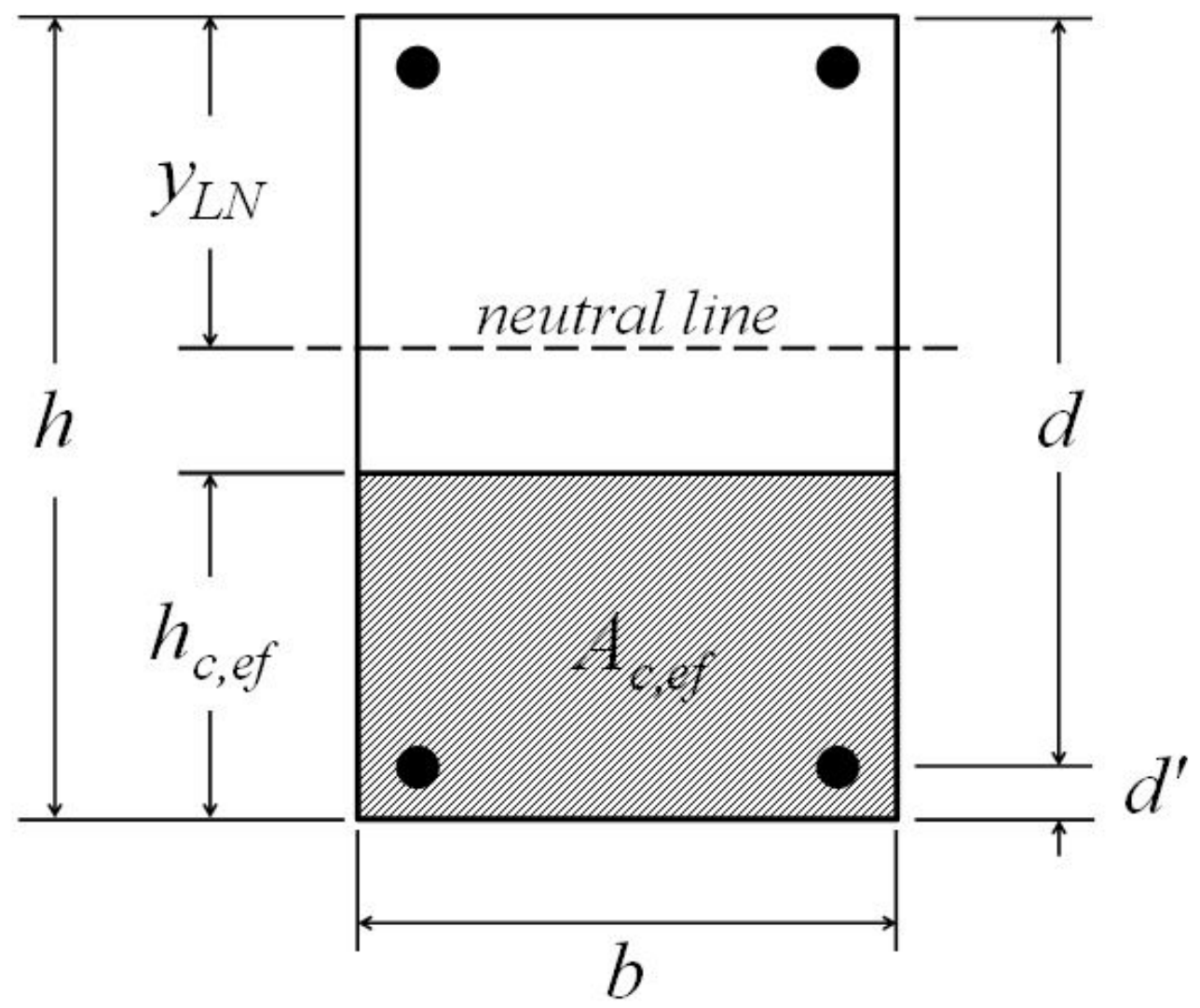

Figure 9. Rectangular block corresponding to the effective tension area.

\section{ANALYSIS PROCESS}

\subsection{Random variables}

Throughout the numerical tests, the following random variables were admitted, width of the cross-section (b), overall depth of the cross-section (h), effective depth of the cross-section (d), compressive strength of concrete $\left(f_{c}\right)$, yield strength of reinforcement $\left(f_{\mathrm{y}}\right)$, permanent loading $\left(\mathrm{F}_{\mathrm{g}}\right)$ and variable loading $\left(\mathrm{F}_{\mathrm{q}}\right)$.

In this case, they are not mean, characteristic, or design values. Random variables are those for which values are generated from a draw that follows a probability density function (PDF). In turn, this function is defined based on an analysis of the behavior of the considered physical quantity. Therefore, a nomenclature is used to differentiate such values, generated by drawing lots, from their respective representative values. The randomly generated values correspond to the values that would actually occur in the structure, without any coefficient.

The probability density function adopted for each variable, as well as the mean $(\mu)$ and standard deviation $(\sigma)$ of the respective distribution, were chosen according to Table 1, based on Magalhães et al. [11], Damas [3] and Barbosa [4]. All distributions of random variables were automatically generated by the computational algorithm developed. 
Table 1. Random variables.

\begin{tabular}{|c|c|c|c|}
\hline Random variable & Distribution & Mean $(\mu)$ & Standard deviation $(\sigma)$ \\
\hline Compressive strength of concrete $\left(f_{\mathrm{c}}\right)$ & Normal & $\begin{array}{c}\mu_{f_{c}}=\frac{f_{c k}}{1-1.645 V_{f_{c}}} \text { where } \\
V_{f_{c}}=0.10\end{array}$ & $\sigma_{f_{c}}=\mu_{f_{c}} \quad V_{f_{c}}$ where $V_{f_{c}}=0.10$ \\
\hline Yield strength of reinforcement $\left(f_{\mathrm{y}}\right)$ & Normal & $\mu_{\mathrm{f}_{\mathrm{y}}}=1.09 \mathrm{f}_{\mathrm{yk}}$ & $\sigma_{\mathrm{f}_{\mathrm{y}}}=0.05 \mu_{\mathrm{f}_{\mathrm{y}}}$ \\
\hline Width of the cross-section (b) & Normal & $\begin{array}{c}\mu_{\mathrm{b}}=\mathrm{b} \\
\text { (nominal design value) }\end{array}$ & $\sigma_{\mathrm{b}}=0.5 \mathrm{~cm}$ \\
\hline Overall depth of the cross-section (h) & Normal & $\begin{array}{c}\mu_{\mathrm{h}}=\mathrm{h} \\
\text { (nominal design value) }\end{array}$ & $\sigma_{\mathrm{h}}=0.5 \mathrm{~cm}$ \\
\hline $\begin{array}{l}\text { Effective depth of the cross-section (d), } \\
\text { taking } \mathrm{d}<\mathrm{h}\end{array}$ & Normal & $\begin{array}{c}\mu_{\mathrm{d}}=\mathrm{d} \\
\text { (nominal design value) }\end{array}$ & $\sigma_{\mathrm{d}}=0.5 \mathrm{~cm}$ \\
\hline Permanent load $\left(\mathrm{F}_{\mathrm{g}}\right)$ & Normal & $\mu_{\mathrm{F}_{\mathrm{g}}}=1.05 \mathrm{~F}_{\mathrm{gk}}$ & $\sigma_{\mathrm{F}_{\mathrm{g}}}=0.10 \mu_{\mathrm{F}_{\mathrm{g}}}$ \\
\hline Variable load $\left(\mathrm{F}_{\mathrm{q}}\right)$ & Gumbel max. & $\begin{array}{c}\mu_{\mathrm{F}_{\mathrm{q}}}=\mathrm{F}_{\mathrm{qk}} \\
\text { (characteristic value) }\end{array}$ & $\sigma_{\mathrm{F}_{\mathrm{q}}}=0.25 \mu_{\mathrm{F}_{\mathrm{q}}}$ \\
\hline
\end{tabular}

\subsection{Analysis procedure}

The Monte Carlo method was used to determine the mean, standard deviation, and probability distribution for the ultimate loads of the mechanical model $\left(\mathrm{F}_{\mathrm{u}, \mathrm{mod}}\right)$. Through the analysis of the moving average, it was observed that statistical convergence occurs from two hundred tests, in most cases. For standardization purposes, five hundred simulations were adopted for all columns, as in Magalhães [2], Damas [3], and Barbosa [4]. Subsequently, the FORM was adopted based on data obtained by the Monte Carlo method.

The design load combination was considered, according to Equation 32, based on the Brazilian Standard NBR 8681 [12].

$\mathrm{F}_{\mathrm{Sd}}=\gamma_{\mathrm{g}} \mathrm{F}_{\mathrm{gk}}+\gamma_{\mathrm{q}} \mathrm{F}_{\mathrm{qk}}$

where $F_{S d}$ is the maximum design load that can be applied to the column, $\gamma_{\mathrm{g}}=1.4$ represents the partial factor for permanent loads, and $\gamma_{\mathrm{q}}=1.4$ represents the partial factor for variable loads. This consideration is only valid for grouped loads referring to buildings whose accidental loads do not exceed $5 \mathrm{kN} / \mathrm{m}^{2}$, in accordance with the Brazilian Standard NBR 8681 [12].

The process used for reliability analysis by Monte Carlo and FORM is shown in the Figure 10. To calculate the average values of the permanent and variable loads from the load combinations, the inverse process is conducted, so that the safety factors are removed to allow comparison with the failure values. For all cases, the FORM is applied using the mean value, the standard deviation value, and the corresponding probability distribution of the failure loads, determined by the Monte Carlo method.

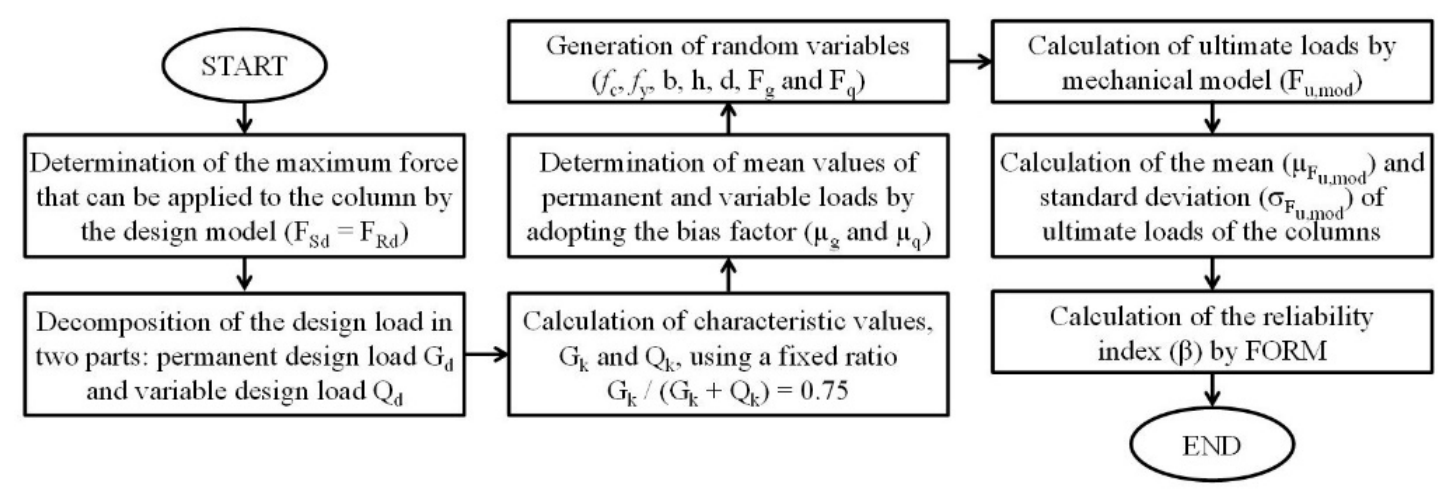

Figure 10. Reliability analysis process by Monte Carlo and FORM. 


\subsection{Model error}

According to Magalhães [2], the model error ( $\left.\mathrm{e}_{\text {model }}\right)$ considers the imprecision of the numerical model used in the analysis. Its value can be estimated using Equation 33, based on Mirza and Skrabek [13], and Magalhães [2]. For this purpose, the coefficient of variation of column strength due to inaccuracies in the theoretical model $\mathrm{V}_{\text {model }}$ is calculated using Equation 34.

$\mathrm{e}_{\text {model }}=\mu_{\text {model }}\left(1+\mathrm{z} \mathrm{V}_{\text {model }}\right)$

where $\mu_{\text {model }}=1.0$ and $\mathrm{z}$ is a Gaussian random variable with zero mean and standard deviation equal to one.

$\mathrm{V}_{\text {model }}=\sqrt{\mathrm{V}_{\mathrm{t} / \mathrm{c}}{ }^{2}-\mathrm{V}_{\text {in-batch }}{ }^{2}-\mathrm{V}_{\text {test }}^{2}}$

where $\mathrm{V}_{\mathrm{t} / \mathrm{c}}$ is the coefficient of variation of the ratio of test to computed strengths, $\mathrm{V}_{\text {in-batch }}$ is the coefficient of variation of column strength due to in-batch variabilities of all variables affecting its strength, and $V_{\text {test }}$ is the coefficient of variation of column strength due to testing procedures. Based on data from the columns considered in this article, it was assumed that $\mathrm{V}_{\text {test }}=0.04$ and $\mathrm{V}_{\text {in-batch }}=0.044$.

Then, the corrected value of the ultimate loads $\left(\mathrm{F}_{\mathrm{u}}\right)$ is obtained by Equation 35 .

$\mathrm{F}_{\mathrm{u}}=\mathrm{e}_{\text {model }} \mathrm{F}_{\mathrm{u}, \mathrm{mod}}$

\subsection{FORM}

When the probability distribution of the variables is known, the First Order Reliability Method (FORM) can be used. Based on Szerszen and Nowak [14], the general format of the limit state function presented in Equation 36 was adopted.

$\mathrm{g}=\mathrm{R}-\mathrm{S}=\mathrm{e}_{\text {model }} \mathrm{F}_{\mathrm{u}, \bmod }-\left(\mathrm{F}_{\mathrm{g}}+\mathrm{F}_{\mathrm{q}}\right)$

where $\mathrm{g}$ is the safety margin, $\mathrm{R}$ is the resistance (ultimate load), and $\mathrm{S}$ represents the effects of the load given by a combination of load components.

From Equation 36, a limit state surface is defined when $g=0$, separating the failure domain $(\mathrm{g}<0)$ from the safety domain ( $g>0$ ). The FORM algorithm of Magalhães [2] was used to determine the reliability index $\beta$, according to the flowchart in Figure 11.

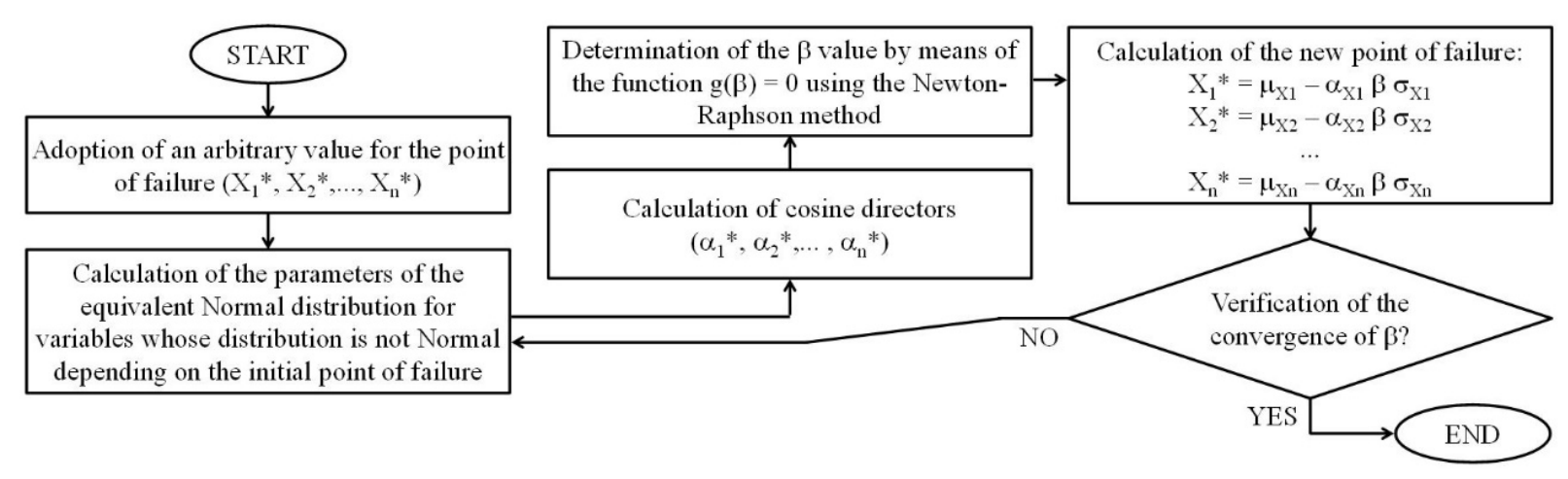

Figure 11. Flowchart of the FORM algorithm. 


\section{MODEL VALIDATION}

It is necessary to validate the mechanical model for its use in determining the ultimate loads. For this, a summary of characteristics of the columns considered in the model validation is shown in Table 2, where $\mathrm{n}$ indicates the number of columns for each reference, including the value of concrete compressive strength $f_{\mathrm{c}}$ measured in the tests and provided by the authors, reinforcement ratio $\rho$, slenderness index $\lambda$, and first-order relative eccentricity $\mathrm{e}_{1} / \mathrm{h}$.

Table 2. Main characteristics of the columns considered in the model validation.

\begin{tabular}{|c|c|c|c|c|c|c|}
\hline Reference & $\mathbf{n}$ & $\begin{array}{c}\text { Cross-section }(\mathrm{cm} \mathrm{x} \\
\mathrm{cm})\end{array}$ & $f_{\mathrm{c}}(\mathrm{MPa})$ & $\rho(\%)$ & $\lambda$ & $\mathbf{e}_{1} / \mathbf{h}$ \\
\hline \multicolumn{7}{|c|}{ Short-term loading } \\
\hline Claeson and Gylltoft [15] & 12 & $12 \times 12$ or $20 \times 20$ & 33.0 to 93.0 & 1.99 to 3.11 & 52 to 69 & 0.10 to 0.17 \\
\hline Dantas [16] & 5 & $25 \times 12$ & 33.9 to 37.6 & 1.57 & 87 & 0.12 to 0.50 \\
\hline Enciso [17] & 4 & $25 \times 15$ & 46.9 to 53.6 & 1.26 to 4.29 & 69 & 0.13 \\
\hline Goyal and Jackson [18] & 26 & $7.62 \times 7.62$ & 19.9 to 23.6 & 1.72 to 2.45 & 55 to 125 & 0.17 to 0.50 \\
\hline Kim and Lee [19] & 4 & $10 \times 10$ or $20 \times 10$ & 27.0 & 2.13 to 2.84 & 42 & 0.40 \\
\hline Kim and Yang [20] & 18 & $8 \times 8$ & 25.5 to 86.2 & 1.98 to 3.95 & 62 to 104 & 0.30 \\
\hline Melo [21] & 17 & $25 \times 12$ & 37.2 to 45.8 & 1.57 & 58 to 87 & 0.05 to 0.50 \\
\hline \multicolumn{7}{|c|}{ Sustained loading } \\
\hline Goyal and Jackson [18] & 20 & $7.62 \times 7.62$ & 19.9 to 23.6 & 1.72 to 2.45 & 55 to 125 & 0.17 to 0.50 \\
\hline Kordina [22] & 10 & $\begin{array}{l}26.4 \leq \mathrm{b} \leq 27.2 \\
17.2 \leq \mathrm{h} \leq 17.6\end{array}$ & 20.9 to 27.1 & 0.98 to 3.19 & 101 to 104 & 0.20 to 0.50 \\
\hline Ramu et al. [23] & 8 & $25 \times 15$ & 21.5 to 37.2 & 1.66 to 4.21 & 100 & 0.03 to 0.25 \\
\hline
\end{tabular}

The model results $F_{\text {mod }}$ were compared with the experimental values $F_{\text {exp }}$ of 124 columns, obtaining the ratio $\mathrm{F}_{\text {exp }} / \mathrm{F}_{\text {mod. }}$. Square and rectangular section columns were considered, with different reinforcement arrangements. As it can be seen in Table 2, elements subjected to short-term and sustained loadings were considered.

For all columns with a rectangular cross-section, the element was subjected to an eccentric compression load applied in the direction of the lowest moment of inertia. The effective creep coefficient $\phi_{\text {ef }}$ was calculated for the columns subjected to sustained loading, whose value varied between 0.75 and 1.60 . This value was obtained from data from columns subjected to long-term load considered for validation purposes, being a variable value dependent on several parameters.

Based on Klein et al. [24], the set of values was divided into groups to verify the distribution of the experimental database for the main characteristics to be considered in the parametric analysis, as shown in Figure 12. Despite noting that the distribution of data is not uniform, results were obtained within the various groups considered. It is also noteworthy that thirty-eight columns were subjected to sustained loading, allowing the analysis of the effects of concrete creep.

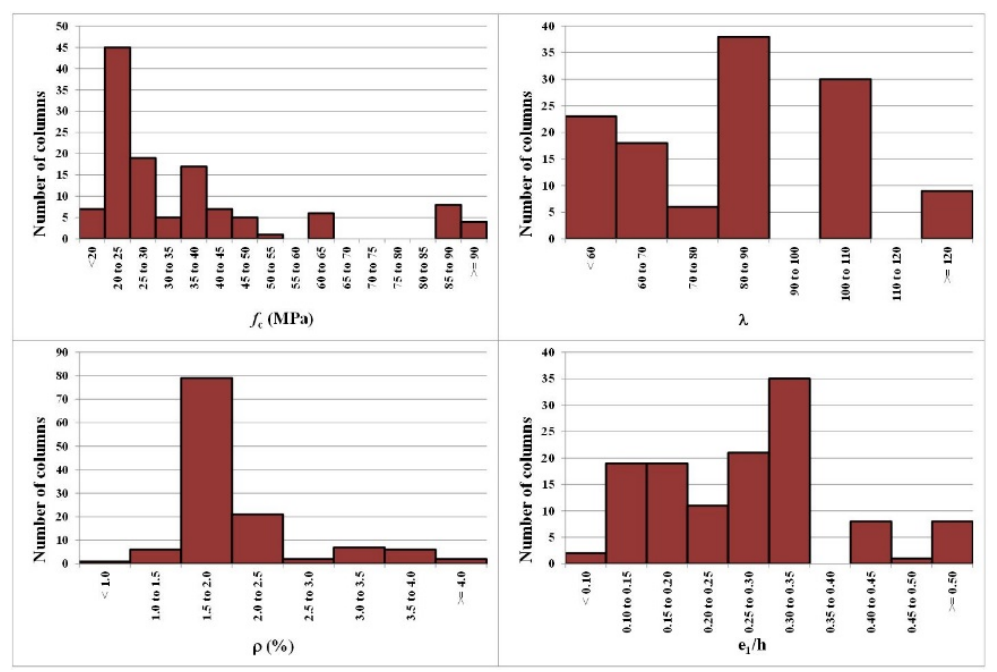

Figure 12. Distribution of database variables. 
Thus, it can be supposed that the parameters considered to determine the model error can adjust the behavior of the mechanical model to the experimental data. Finally, it is observed that the results obtained are consistent with the results of the experimental tests, as shown in Table 3.

Table 3. Statistical synthesis of results of the validation process.

\begin{tabular}{ccccccc}
\hline Ratio & Minimum & Maximum & Range & Mean & $\begin{array}{c}\text { Standard } \\
\text { deviation }\end{array}$ & $\mathbf{V}_{\text {model }}$ \\
\hline $\mathbf{F}_{\text {exp }} / \mathbf{F}_{\text {mod }}$ & 0.75 & 1.31 & 0.56 & 0.99 & 0.10 & 0.08 \\
\hline
\end{tabular}

\section{NUMERICAL RESULTS}

\subsection{Numerical test program}

To conduct the numerical test program, the characteristics of the elements to be assessed are defined. The square cross-section was chosen, with the reinforcement arrangements shown in Figure 13.
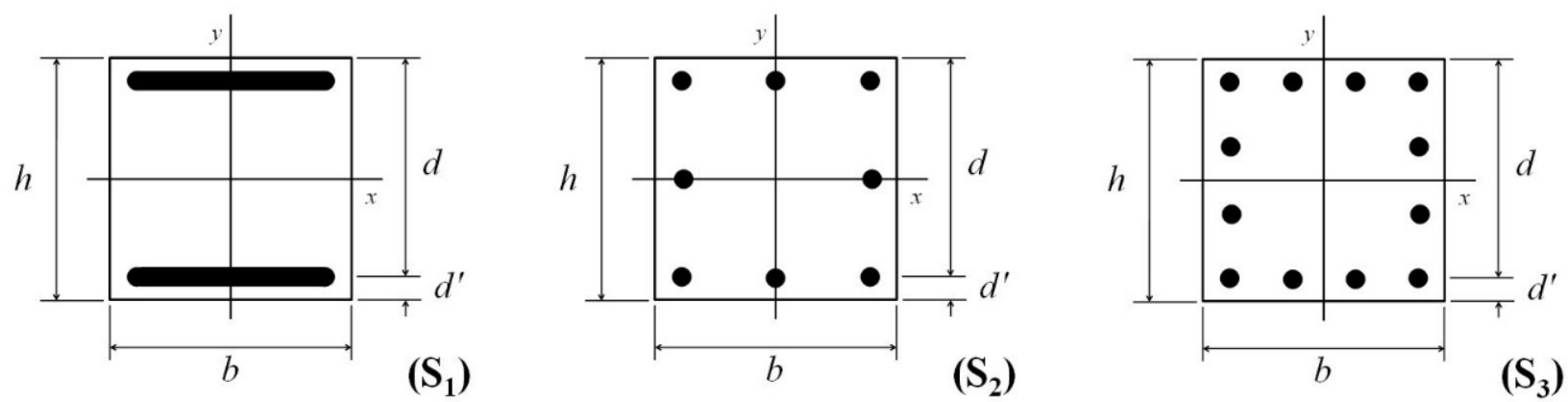

Figure 13. Cross-sections of the columns considered in the research.

For testing purposes, a square cross-section with a width of $40 \mathrm{~cm}$ was adopted. The experiment was divided into two groups according to the compressive strength of concrete. In each group, 108 models were defined from the variation of the parameters, totaling 216 elements.

In all columns, $\mathrm{b}=40 \mathrm{~cm}, \mathrm{~h}=40 \mathrm{~cm}$, and $\mathrm{d}^{\prime}=6.0 \mathrm{~cm}\left(\mathrm{~d}^{\prime} / \mathrm{h}=0.15\right)$ were considered. The reinforcement ratio $(\rho)$ was varied from 0.75 to $3.00 \%$. Three levels of slenderness were considered, varying the length of the element, adopting the slenderness index $(\lambda)$ between 100 and 140. For the first-order relative eccentricity $\left(\mathrm{e}_{1} / \mathrm{h}\right)$, ratios between 0.12 and 0.24 were adopted. Finally, 30 and $60 \mathrm{MPa}$ were adopted for the characteristic compressive strength of concrete $\left(f_{\mathrm{ck}}\right)$.

Concerning the general method, the cross-section was divided into twenty horizontal strips for integration purposes. The variation $\Delta \theta=1$ was adopted, with a precision of 0.1 for the curvature related to the rupture, with the depth of the neutral line varying by $0.1 \mathrm{~cm}$. The column was divided into ten sections to determine the second-order local effects by the finite difference method, with an initial displacement value at the top equal to zero and an increase of $0.001 \mathrm{~cm}$ in the iterative process.

\subsection{Numerical test results}

The results obtained for the reliability index $\beta$ of the columns analyzed in the numerical tests are shown in Table 4. The cross-section is indicated by the letter $\mathrm{S}$ followed by a number corresponding to the respective drawing shown in Figure 13. 
Table 4. Reliability index of the tested columns.

\begin{tabular}{|c|c|c|c|c|c|c|c|c|}
\hline \multirow{3}{*}{ Cross-section } & \multirow{3}{*}{$\mathbf{e}_{1} / \mathbf{h}$} & \multirow{3}{*}{$\rho(\%)$} & \multicolumn{3}{|c|}{$f_{\mathrm{ck}}=30 \mathrm{MPa}$} & \multicolumn{3}{|c|}{$f_{\mathrm{ck}}=60 \mathrm{MPa}$} \\
\hline & & & \multicolumn{3}{|c|}{ Slenderness ratio $(\lambda)$} & \multicolumn{3}{|c|}{ Slenderness ratio $(\lambda)$} \\
\hline & & & 100 & 120 & 140 & 100 & 120 & 140 \\
\hline \multirow{12}{*}{ S1 } & \multirow{4}{*}{0.12} & 0.75 & 4.15 & 4.15 & 4.26 & 3.87 & 3.93 & 3.99 \\
\hline & & 1.50 & 3.77 & 3.84 & 3.82 & 3.65 & 3.67 & 3.71 \\
\hline & & 2.25 & 3.53 & 3.53 & 3.56 & 3.48 & 3.47 & 3.50 \\
\hline & & 3.00 & 3.47 & 3.32 & 3.36 & 3.37 & 3.33 & 3.35 \\
\hline & \multirow{4}{*}{0.18} & 0.75 & 4.02 & 4.14 & 4.27 & 3.99 & 4.16 & 4.31 \\
\hline & & 1.50 & 3.58 & 3.57 & 3.63 & 3.52 & 3.59 & 3.70 \\
\hline & & 2.25 & 3.47 & 3.38 & 3.29 & 3.36 & 3.31 & 3.32 \\
\hline & & 3.00 & 3.51 & 3.30 & 3.21 & 3.35 & 3.23 & 3.17 \\
\hline & \multirow{4}{*}{0.24} & 0.75 & 3.88 & 3.98 & 4.02 & 4.01 & 4.11 & 4.36 \\
\hline & & 1.50 & 3.60 & 3.49 & 3.41 & 3.50 & 3.51 & 3.53 \\
\hline & & 2.25 & 3.49 & 3.38 & 3.31 & 3.45 & 3.35 & 3.29 \\
\hline & & 3.00 & 3.54 & 3.29 & 3.26 & 3.29 & 3.30 & 3.19 \\
\hline \multirow{12}{*}{ S2 } & \multirow{4}{*}{0.12} & 0.75 & 4.27 & 4.33 & 4.41 & 3.97 & 4.04 & 4.17 \\
\hline & & 1.50 & 3.96 & 4.04 & 4.04 & 3.81 & 3.86 & 3.88 \\
\hline & & 2.25 & 3.71 & 3.73 & 3.77 & 3.65 & 3.64 & 3.70 \\
\hline & & 3.00 & 3.53 & 3.52 & 3.56 & 3.47 & 3.47 & 3.51 \\
\hline & \multirow{4}{*}{0.18} & 0.75 & 4.26 & 4.38 & 4.50 & 4.16 & 4.35 & 4.59 \\
\hline & & 1.50 & 3.75 & 3.77 & 3.81 & 3.73 & 3.80 & 3.93 \\
\hline & & 2.25 & 3.56 & 3.52 & 3.50 & 3.48 & 3.48 & 3.52 \\
\hline & & 3.00 & 3.52 & 3.38 & 3.39 & 3.39 & 3.33 & 3.33 \\
\hline & \multirow{4}{*}{0.24} & 0.75 & 4.08 & 4.16 & 4.34 & 4.21 & 4.38 & 4.65 \\
\hline & & 1.50 & 3.75 & 3.61 & 3.67 & 3.62 & 3.74 & 3.71 \\
\hline & & 2.25 & 3.57 & 3.54 & 3.47 & 3.55 & 3.45 & 3.48 \\
\hline & & 3.00 & 3.53 & 3.43 & 3.39 & 3.47 & 3.42 & 3.32 \\
\hline \multirow{12}{*}{ S3 } & \multirow{4}{*}{0.12} & 0.75 & 4.30 & 4.40 & 4.45 & 3.99 & 4.01 & 4.20 \\
\hline & & 1.50 & 4.00 & 4.07 & 4.09 & 3.80 & 3.88 & 3.91 \\
\hline & & 2.25 & 3.74 & 3.79 & 3.83 & 3.67 & 3.68 & 3.73 \\
\hline & & 3.00 & 3.55 & 3.56 & 3.58 & 3.49 & 3.51 & 3.56 \\
\hline & \multirow{4}{*}{0.18} & 0.75 & 4.29 & 4.43 & 4.54 & 4.18 & 4.38 & 4.60 \\
\hline & & 1.50 & 3.77 & 3.81 & 3.90 & 3.72 & 3.82 & 3.97 \\
\hline & & 2.25 & 3.57 & 3.55 & 3.55 & 3.54 & 3.52 & 3.58 \\
\hline & & 3.00 & 3.53 & 3.44 & 3.39 & 3.44 & 3.37 & 3.36 \\
\hline & \multirow{4}{*}{0.24} & 0.75 & 4.15 & 4.25 & 4.37 & 4.22 & 4.48 & 4.70 \\
\hline & & 1.50 & 3.74 & 3.66 & 3.74 & 3.66 & 3.77 & 3.74 \\
\hline & & 2.25 & 3.60 & 3.58 & 3.50 & 3.61 & 3.48 & 3.54 \\
\hline & & 3.00 & 3.52 & 3.49 & 3.41 & 3.52 & 3.42 & 3.35 \\
\hline
\end{tabular}




\section{RESULTS ANALYSIS}

For the analysis of the obtained results, curves were drawn that relate the reliability index and the reinforcement ratio, as shown in Figure 14. It is also possible to evaluate the variation in the slenderness index and the compressive strength of concrete, among other parameters.
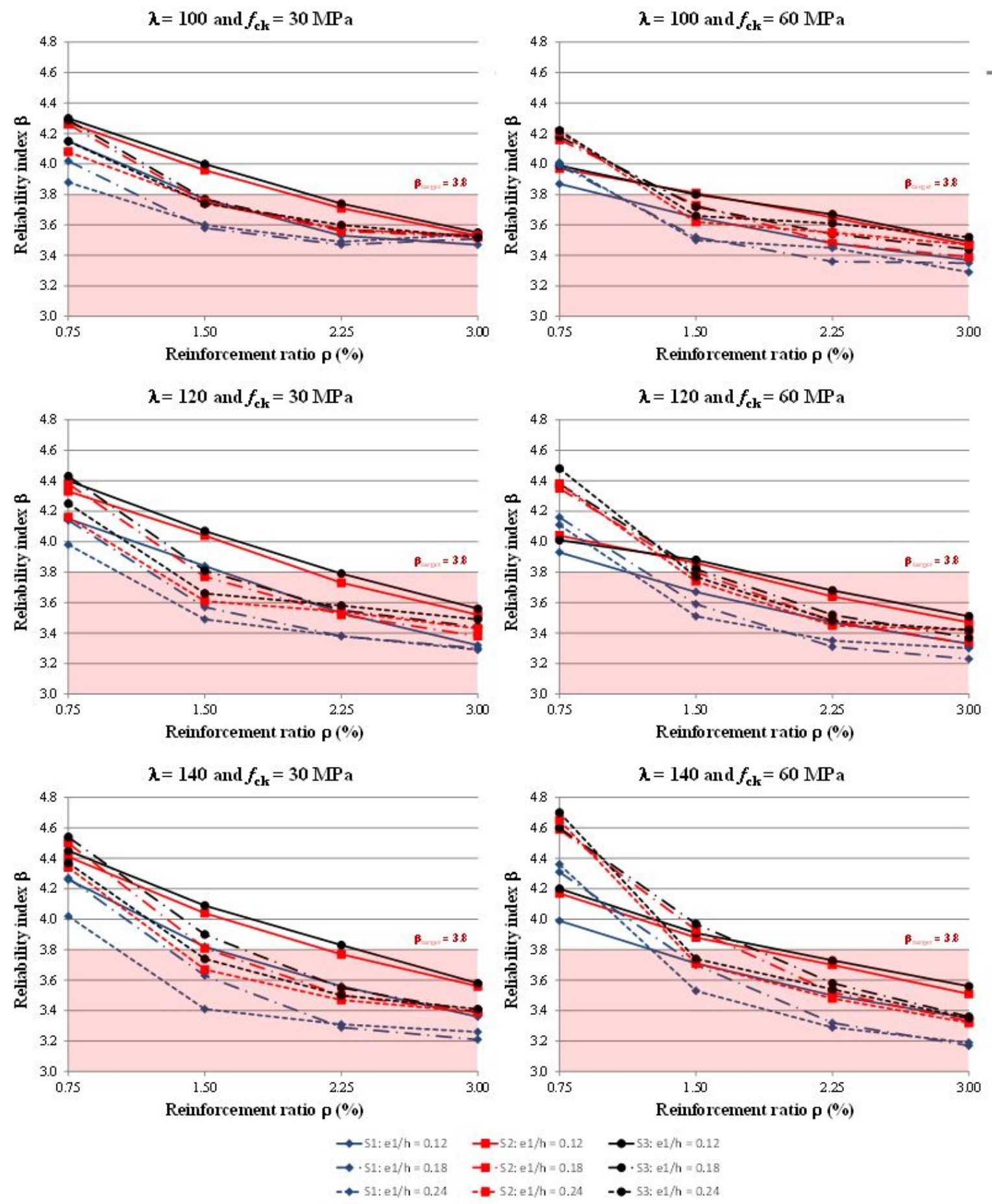

Figure 14. Comparative analysis of results. 
In general, there is a reduction in reliability as the reinforcement ratio increases. Concerning the first-order relative eccentricity, the reliability index tends to be higher for smaller eccentricities $\left(\mathrm{e}_{1} / \mathrm{h}=0.12\right)$, but this can change for reduced reinforcement ratios.

Considering the target reliability index $\beta_{\text {target }}$ recommended by Model Code 2010 [25], for the 50 years reference period and the ultimate limit state with a high consequence of failure, $\beta_{\text {target }}=4.3$ should be adopted. For the medium consequence of failure, $\beta_{\text {target }}=3.8$ is recommended. In turn, if the relative cost of safety measure is moderate, $\beta_{\text {target }}=$ 3.8 can be adopted for a great consequence of failure. It is not recommended to use smaller values due to the high probability of failure. The Brazilian Standard NBR 6118 [1] does not mention the target reliability index. For this reason, the value recommended by the Model Code 2010 [25] is used as a reference.

When analyzing Table 4, together with Figure 14, it is observed that the average reliability index is equal to 3.76 and the median is equal to 3.62 for $f_{\text {ck }}=30 \mathrm{MPa}$. That is, the values obtained are close to 3.8 . For $f_{\text {ck }}=60 \mathrm{MPa}$, the situation is similar, with a mean of 3.71 and a median of 3.63 .

It is observed that all columns with a reinforcement ratio $\rho$ equal to $0.75 \%$ have a reliability index higher than 3.8 for $f_{\mathrm{ck}}=30 \mathrm{MPa}$ and $f_{\mathrm{ck}}=60 \mathrm{MPa}$. On the other hand, all columns with a reinforcement ratio equal to $3.00 \%$ have a lower reliability index. It is considered that it would be important to improve the design criteria of the Brazilian Standard NBR 6118 [1] to obtain higher values for the reliability index of columns, to meet the design recommendations.

According to Nowak and Collins [26], the safety margin is determined from the difference between the resistance $\mathrm{R}$ and the load effect $\mathrm{S}$, allowing the determination of the probability of failure. To analysis, the probability density function curves were plotted for columns with $f_{\text {ck }}=30 \mathrm{MPa}, \lambda=120$ and $\mathrm{e}_{1} / \mathrm{h}=0.18$. The reinforcement ratio $\rho$ and the reinforcement arrangement in the cross-section were varied, as shown in Figure 15, where S indicates the load effect; $\mathrm{R}$ indicates resistance; $\mu_{\mathrm{S}}$ and $\sigma_{\mathrm{S}}$ indicate the mean and standard deviation of the load effect; $\mu_{\mathrm{R}}$ and $\sigma_{\mathrm{R}}$ indicate the mean and standard deviation of the resistance; S1, S2, and S3 indicate the cross-section; $0.75 \%$ and $3.00 \%$ indicate the respective reinforcement ratio.

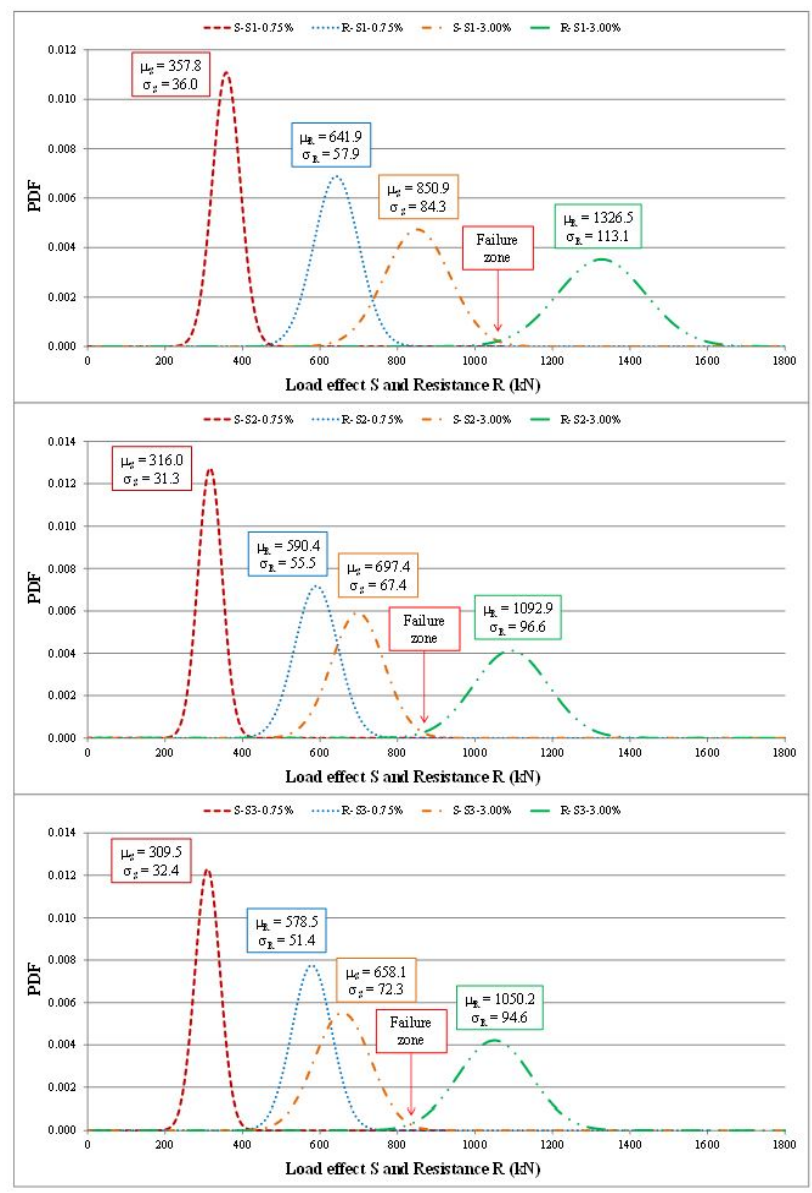

Figure 15. Analysis of load effect and resistance by probability density function (PDF). 
It is observed graphically that the probability of failure $P_{F}$ increases with the increase in the reinforcement ratio $\rho$, as a greater region of overlap (failure zone) between the load effect and the resistance curves is visualized. An analysis of the load effect $S$, resistance $R$, and the respective safety margin $g(R, S)$ can be performed by determining the respective mean $\mu$, standard deviation $\sigma$ and coefficient of variation COV values, as shown in Table 5 .

Table 5. Analysis of load effect, resistance, and safety margin.

\begin{tabular}{|c|c|c|c|c|c|c|c|c|c|c|}
\hline \multirow{3}{*}{ Parameter } & \multirow{3}{*}{ Measure } & \multicolumn{3}{|c|}{$\begin{array}{c}\text { Cross-section } \mathrm{S} 1 f_{\mathrm{ck}}=30 \mathrm{MPa} \\
\lambda=120 \mathrm{e}_{1} / \mathrm{h}=0.18\end{array}$} & \multicolumn{3}{|c|}{$\begin{array}{c}\text { Cross-section S2 } f_{\mathrm{ck}}=30 \mathrm{MPa} \\
\lambda=120 \mathrm{e}_{1} / \mathrm{h}=0.18\end{array}$} & \multicolumn{3}{|c|}{$\begin{array}{c}\text { Cross-section } \mathrm{S3} f_{\text {ck }}=30 \mathrm{MPa} \\
\lambda=120 \mathrm{e}_{1} / \mathrm{h}=0.18\end{array}$} \\
\hline & & (1) & (2) & & (3) & (4) & & (5) & (6) & \\
\hline & & $\begin{array}{c}\rho= \\
0.75 \%\end{array}$ & $\begin{array}{c}\rho= \\
3.00 \%\end{array}$ & $(2) /(1)$ & $\begin{array}{c}\rho= \\
0.75 \%\end{array}$ & $\begin{array}{c}\rho= \\
3.00 \%\end{array}$ & (4)/(3) & $\begin{array}{c}\rho= \\
0.75 \%\end{array}$ & $\begin{array}{c}\rho= \\
3.00 \%\end{array}$ & $(6) /(5)$ \\
\hline \multirow{3}{*}{ Load effect $S$} & $\boldsymbol{\mu}(\mathrm{kN})$ & 357.8 & 850.9 & 2.38 & 316.0 & 697.4 & 2.21 & 309.5 & 658.1 & 2.13 \\
\hline & $\boldsymbol{\sigma}(\mathrm{kN})$ & 36.0 & 84.3 & 2.34 & 31.3 & 67.4 & 2.15 & 32.4 & 72.3 & 2.23 \\
\hline & $\mathrm{COV}$ & 0.10 & 0.10 & 0.98 & 0.10 & 0.10 & 0.98 & 0.10 & 0.11 & 1.05 \\
\hline \multirow{3}{*}{ Resistance $\mathbf{R}$} & $\boldsymbol{\mu}(\mathrm{kN})$ & 641.9 & 1326.5 & 2.07 & 590.4 & 1092.9 & 1.85 & 578.5 & 1050.2 & 1.82 \\
\hline & $\boldsymbol{\sigma}(\mathrm{kN})$ & 57.9 & 113.1 & 1.95 & 55.5 & 96.6 & 1.74 & 51.4 & 94.6 & 1.84 \\
\hline & $\mathrm{COV}$ & 0.09 & 0.09 & 0.95 & 0.09 & 0.09 & 0.94 & 0.09 & 0.09 & 1.01 \\
\hline \multirow{3}{*}{$\begin{array}{l}\text { Safety margin } \\
\qquad \mathrm{g}(\mathrm{R}, \mathrm{S})\end{array}$} & $\boldsymbol{\mu}(\mathrm{kN})$ & 284.1 & 475.6 & 1.67 & 274.4 & 395.5 & 1.44 & 269.0 & 392.1 & 1.46 \\
\hline & $\boldsymbol{\sigma}(\mathrm{kN})$ & 68.2 & 141.1 & 2.07 & 63.7 & 117.8 & 1.85 & 60.8 & 119.1 & 1.96 \\
\hline & $\mathrm{COV}$ & 0.24 & 0.30 & 1.24 & 0.23 & 0.30 & 1.28 & 0.23 & 0.30 & 1.34 \\
\hline
\end{tabular}

In Table 5 , columns with $f_{\text {ck }}=30 \mathrm{MPa}, \lambda=120$ and $\mathrm{e}_{1} / \mathrm{h}=0.18$ are considered, for cross-sections $\mathrm{S} 1, \mathrm{~S} 2$ and S3. It is observed that the coefficient of variation regarding the load effect is practically the same for all cases. The same occurs with the coefficient of variation of the resistance. However, the mean and standard deviation value increases more sharply for the load effect than the resistance as the reinforcement ratio increases. In this way, the safety margin is reduced, and the reliability index is also reduced.

Therefore, the reliability index reduction is justified by the increase of the load with the reinforcement ratio. This increases the variable load effect, which has the highest coefficient of variation among all random variables. Besides, it is noteworthy that the increase in load leads to a significant rise in second-order effects on slender columns.

It should be noted that, for a previously established reinforcement ratio, the design load is determined according to the NBR 6118 [1] recommendations. It can be seen from Table 5 that the design load obtained with the Brazilian Standard prescriptions increases more sharply than the ultimate load determined by the mechanical model for this slenderness interval.

With the increase in the reinforcement ratio, there is a more significant increase in the load effect in relation to the resistance, as can be seen in Table 5. Therefore, it is observed that the greater variability of the load effect generates a region of higher risk of failure, something that can be seen in Figure 14.

About the cross-section, it is observed that the sections S2 and S3, with reinforcement distributed along the faces, offer a higher reliability index than the section S1, with only two lines of reinforcement. Although S1 presents greater resistance, the distribution of steel bars of the longitudinal reinforcement on the cross-section faces, as in cross-sections $\mathrm{S} 2$ and S3, reduced the mean and standard deviation in both the load effect and resistance. Consequently, there is a reduction in the standard deviation of the safety margin. Also, the load increasing due to the reinforcement ratio increasing is not as significant in S2 and $\mathrm{S} 3$ as in $\mathrm{S} 1$.

\section{CONCLUSIONS}

The general method was presented using the moment-curvature relationship and the finite difference method to consider physical and geometric nonlinearity, respectively. According to the linear creep theory, creep was evaluated with the displacement obtained in the concrete stress-strain diagram in this model. In general, it is emphasized that these are iterative processes that require computational implementation.

A mechanical model was developed to determine the ultimate loads, considering the non-linear model of Eurocode 2 [8] for concrete subjected to compression and the simplified model adapted by Baptista [9] from Collins and Mitchell [10] for tension in concrete, with tension-stiffening effect. For longitudinal reinforcement steel, the perfect elasto-plastic model was considered. 
Regarding numerical tests, it was observed that the reliability index varies according to the reinforcement arrangement and the reinforcement ratio in the cross-section. Higher levels of safety were verified for sections with reinforcement distributed on the faces instead of just two reinforcement lines. The cross-sections with lower reinforcement ratios showed a higher reliability index, with a reduction of the same as the reinforcement ratio increases.

It is observed that the increase in resistance does not necessarily increase the reliability index. This is because structural reliability depends on a statistical analysis that considers the resistance to rupture in the mechanical model and the value of the design load.

In the analysis of the target reliability index, it was observed that it would be necessary to evaluate the implementation of an additional safety coefficient in the Brazilian Standard NBR 6118 [1] for columns with slenderness index between $\lambda=90$ and $\lambda=140$. Such normative inclusion would increase the reliability index of very slender columns to ensure that its design leads to safety levels according to technical recommendations.

Finally, it is intended to evaluate a more considerable number of columns in the future, covering a broader range regarding the compressive strength of concrete and the slenderness index.

\section{ACKNOWLEDGEMENTS}

The author K. Ribeiro thanks the Universidade Federal de Santa Catarina (UFSC), the Coordenação de Aperfeiçoamento de Pessoal de Nível Superior (Capes), and the Universidade do Estado de Santa Catarina (UDESC). The author M. de V. Real thanks the Conselho Nacional de Desenvolvimento Científico e Tecnológico (CNPq) for the research grant (Process 304211/2018-4).

\section{REFERENCES}

[1] Associação Brasileira de Normas Técnicas, Projeto de Estruturas de Concreto - Procedimento, NBR 6118:2014, 2014.

[2] F. C. Magalhães, "A problemática dos concretos não conformes e sua influência na confiabilidade de pilares de concreto armado," Ph.D. dissertation, PPGEC, UFRGS, Porto Alegre, 2014.

[3] A. P. Damas, "Estudo de confiabilidade no projeto de pilares esbeltos de concreto de alta resistência," M.S. thesis, PPGEC, UFRGS, Porto Alegre, 2015.

[4] P. R. O. Barbosa, “Análise probabilística de pilares de concreto armado através do método dos elementos finitos,” M.S. thesis, PPGEC, UFRGS, Porto Alegre, 2017.

[5] K. Ribeiro, "Diagramas para verificação de pilares retangulares em concreto armado submetidos à flexão composta normal," M.S. thesis, PPGEC, UFSC, Florianópolis, 2011.

[6] P. B. Fusco, Estruturas de Concreto: Solicitações Normais. Rio de Janeiro: Guanabara Dois, 1981.

[7] A. F. Casagrande, "Consideração da fluência no cálculo dos efeitos de segunda ordem em pilares de concreto armado,” M.S. thesis, PPGEC, UFSC, Florianópolis, 2016.

[8] European Committee for Standardization, Eurocode 2: Design of Concrete Structures - Part 1-1: General Rules and Rules for Buildings, EN 1992-1-1:2004, 2004.

[9] F. M. S. Baptista, "Análise de flechas imediatas e diferidas de vigas em concreto armado,” M.S. thesis, PPGEC, UFSC, Florianópolis, 2018.

[10] M. P. Collins and D. Mitchell, Prestressed Concrete Basics. Ontario: Can. Prestressed Concr. Inst., 1987.

[11] F. C. Magalhães, M. V. Real, and L. C. P. Silva Fo., "The problem of non-compliant concrete and its influence on the reliability of reinforced concrete columns," Mater. Struct., vol. 49, pp. 1485-1497, 2015., http://dx.doi.org/10.1617/s11527-015-0590-x.

[12] Associação Brasileira de Normas Técnicas, Ações e Segurança nas Estruturas - Procedimento, NBR 8681:2003, 2003.

[13] S. A. Mirza and B. W. Skrabek, "Reliability of short composite beam-column strength interaction," J. Struct. Eng., vol. 117, no. 8, pp. 2320-2339, Aug 1991, http://dx.doi.org/10.1061/(ASCE)0733-9445(1991)117:8(2320).

[14] M. M. Szerszen and A. S. Nowak, "Calibration of design code for buildings (ACI 318): part 2 - reliability analysis and resistance factors," ACI Struct. J., vol. 100, no. 3, pp. 383-391, May-Jun 2003, http://dx.doi.org/10.14359/12614.

[15] C. Claeson and K. Gylltoft, "Slender high-strength concrete columns subjected to eccentric loading," J. Struct. Eng., vol. 124, pp. 233-240, Mar 1998, http://dx.doi.org/10.1061/(ASCE)0733-9445(1998)124:3(233).

[16] A. B. Dantas, "Estudo de pilares de concreto armado submetidos à flexão composta reta,” M.S. thesis, PECC, UnB, Brasília, 2006.

[17] R. O. Enciso, “Comportamento de pilares esbeltos de concreto de alta resistência sujeitos à flexão composta reta,” M.S. thesis, PPGEC, PUC-Rio, Rio de Janeiro, 2010.

[18] B. B. Goyal and N. Jackson, "Slender concrete columns under sustained load," J. Struct. Div., vol. 97, no. 11, pp. 2729-2750, Nov 1971, http://dx.doi.org/10.1061/JSDEAG.0003050. 
[19] J.-K. Kim and S.-S. Lee, "The behavior of reinforced concrete columns subjected to axial force and biaxial bending," Eng. Struct., vol. 22, no. 11, pp. 1518-1528, Nov 2000, http://dx.doi.org/10.1016/S0141-0296(99)00090-5.

[20] J.-K. Kim and J.-K. Yang, "Buckling behaviour of slender high-strength concrete columns," Eng. Struct., vol. 17, no. 1, pp. 39-51, 1995, http://dx.doi.org/10.1016/0141-0296(95)91039-4.

[21] C. E. L. Melo, “Análise experimental e numérica de pilares birrotulados de concreto armado submetidos a flexo-compressão normal," Ph.D. dissertation, PECC, UnB, Brasília, 2009.

[22] K. Kordina, Langzeitversuche an Stahlbetonstützen. Braunschweig: Inst. Baustoffkunde und Stahlbetonbau, Tech. Univ. Braunschweig, June 1972.

[23] P. Ramu, M. Grenacher, M. Baumann, and B. Thürlimann, Versuche an Gelenkig Gelagerten Stahlbetonstützen unter Dauerlast. Zürich: Institut für Baustatik, Eidgenössische Technische Hochschule Zürich, 1969, https://doi.org/10.3929/ethz-a-004170564.

[24] O. Klein Jr., F. R. Stucchi, and R. L. Barbosa, "Evaluation of Brazilian standard ABNT NBR 6118 procedures for calculating the second-order effects of reinforced concrete slender columns subjected to uniaxial bending," Struct. Concr., vol. 21, no. 1, pp. 81-93, Feb 2020, http://dx.doi.org/10.1002/suco.201800251.

[25] Fédération Internationale du Béton, Model Code 2010: Final Draft, vol. 1 (Bulletin 65). Lausanne, March 2012.

[26] A. S. Nowak and K. R. Collins, Reliability of Structures. Boston: McGraw-Hill, 2000.

Author contributions: KR: conceptualization, methodology, computational programming, numerical tests, results analysis, writing; DDL: conceptualization, methodology, results analysis, supervision; MVR: conceptualization, methodology, results analysis, supervision.

Editors: Yuri Villagrán Zaccardi, Guilherme Aris Parsekian. 